Revista de la red interuniversitaria de estudios sobre las literaturas rioplatenses contemporáneas en Francia

$9 \mid 2013$

Homenaje a Ana María Barrenechea

\title{
Recordando a Anita
}

Ivonne Bordelois

URL: http://journals.openedition.org/lirico/1076

DOI: 10.4000/lirico.1076

ISSN: 2262-8339

Editor

Réseau interuniversitaire d'étude des littératures contemporaines du Río de la Plata

Referencia electrónica

Ivonne Bordelois, «Recordando a Anita », Cuadernos LIRICO [En línea], 9 | 2013, Puesto en línea el 01 septiembre 2013, consultado el 02 mayo 2019. URL : http://journals.openedition.org/lirico/1076 ; DOI : 10.4000/lirico.1076

Este documento fue generado automáticamente el 2 mayo 2019.

\section{(c) $(1) \Theta \Theta$}

Cuadernos LIRICO está distribuido bajo una Licencia Creative Commons Atribución-NoComercialSinDerivar 4.0 Internacional. 


\title{
Recordando a Anita
}

\author{
Ivonne Bordelois
}

1 Decir Anita Barrenechea es abrir la puerta de los años dorados, los sesenta, verla entrar en clase - con un famoso traje de gamuza celeste inolvidable - y encontrarnos con el Mío Cid, con Amado Alonso, con los escarceos del estructuralismo ad usum nostrum.

2 En la mediocridad de la Facultad que el peronismo y las mezquinas peleas posteriores al peronismo habían diezmado, existía un rayo de luz, de humor, de connivencia con los estudiantes, y esa luminosidad se llamaba Ana María Barrenechea. Por esa puerta entró Alejandra Pizarnik y de allí arrancó su poco conocido amor por el cancionero y el romancero medieval español, que inspira algunos de sus poemas más conmovedores. Pero Anita era una señal de inspiración para las rutas más distintas : yo recuerdo en particular mis discusiones con ella acerca del célebre Sistema de los Tiempos Verbales de Andrés Bello, mi primera polémica lingüística, que logró volver aún más acendrado mi amor por las estructuras complejas y cristalinas de la flexión española, en cuya descripción nos enzarzábamos con tanta pasión como amistad.

3 Cuando los decretos de Onganía nos empujaron fuera del país, Anita fue crucial en mi ingreso a MIT, en los Estados Unidos. De hecho, después de haber aceptado mi solicitud de ingreso al Departamento de Lingüística donde campeaba el nuevo paradigma encarnado por Chomsky, las autoridades me notificaron por carta que habían suspendido mi inscripción, ya que para ese entonces yo no contaba con los recursos necesarios para pagar los cuantiosos aranceles que a esos niveles internacionales se estilan. Anita enseñaba en Harvard en ese momento, y sin arredrarse ante las ominosas noticias que le llegaron acerca de este descalabro, se presentó ante el decano del Departamento en MIT, un poderoso letón llamado Morris Halle, y prácticamente le exigió que se revisara la funesta decisión que me descartaba de los caminos del doctorado.

4 Mientras tanto, después de arduos esfuerzos, yo lograba en Buenos Aires que el CONICET me otorgara una generosa beca externa que aseguraba mi lujoso financiamiento, y todo se resolvió después de un angustiante suspenso en que todo el trámite estuvo a punto de perderse definitivamente, a no ser por la milagrosa prórroga lograda por la presencia y la determinación de Anita. En ese sentido, le debo en parte mi carrera a su resuelta intervención en mi favor, un arriesgado gesto que la experiencia me ha enseñado a 
considerar totalmente excepcional dentro de las pautas acostumbradas de la muy reducida generosidad que reina en el mundo académico.

Aparte de esta deuda de gratitud irrenunciable, evocarla no es tarea fácil para mí. En realidad, cuando intentamos retratar la figura de Anita y hacerla presente a aquellos que la conocieron menos o más tardíamente, tropezamos con una evidente dificultad, y es que, a pesar de su espontaneidad y de la sencillez con que se brindaba, su personalidad era indudablemente compleja : había en ella una curiosa mezcla de lucidez e ingenuidad, de recato y audacia, de fantasía y rigor, de humor y austeridad, que la vuelven insustituible y algo inexplicable y misteriosa en nuestra memoria. Era a la vez un ejemplo de catolicismo practicante y de progresismo político, y asimismo un testimonio viviente de hispanismo filológico y de contemporaneidad literaria : en efecto, apartándose de las pautas convencionales, introducía, con detalle apasionado, a un Cortázar que todavía no era célebre tan pronto como criticaba ásperamente al prestigioso Todorov, a su juicio eurocéntrico y soberbio. Era nuestra amiga confiable y era también el pilar y la referencia insoslayable de la Facultad en cuanto a autoridad moral y a coherencia de trayectoria democrática : dejó su puesto cuando se le exigía el diezmo para la Fundación Eva Perón y volvió a dejarlo cuando Onganía entró a sangre y fuego en la Universidad; memorablemente, se apartó de la Dirección del Instituto de Filología, después de varias décadas a su servicio, para dejar el paso a sus posibles sucesores. No son muchos, en verdad, los que hoy pueden jactarse de haber seguido su ejemplo.

6 Su presencia está incluida para mí en esa guirnalda de amistades irremplazables que fueron el privilegio de aquellos años felices : Enrique Pezzoni, Alejandra Pizarnik, Susana Thénon, Isaías Lerner : una ronda de permanente humor, brillantez, poesía desde la más altas cumbres, crítica de avanzada, lecturas y noches compartidas, juegos de diccionario, anécdotas, burlas cariñosas - como aquel título que Alejandra había infligido a nuestras investigaciones gramaticales: El veranoide y los verboides. Sin pedantería, con un permanente afán de entender y entendernos mejor, sin pretensiones curriculares, en un ambiente de mutua admiración y permanente regocijo, pero también con la infinita seriedad que corresponde a quienes se internan de verdad en los milagrosos misterios del lenguaje, nuestro grupo transcurría esas épocas de investigaciones intensas y hallazgos sorprendentes sin sospechar el ominoso futuro que nos aguardaba y terminaría dispersándonos por el mundo, lejos los unos de los otros.

7 Maestra y amiga, personaje inolvidable, cifra de todo un mundo intelectual hoy lamentablemente desaparecido en su dimensión de gracia y gratuidad: todo eso es Ana María Barrenechea para nosotros, en el recuerdo y en la nostalgia. A la memorable foto de Enrique Pezzoni que retrata su hermoso rostro apoyado contra un recio tronco, yo puedo añadir en la galería de los recuerdos otra foto tomada en Uruguay, donde asistimos a un simposio lingüístico, en la que ella flamea en la arena de una playa con una suerte de capelina ondulante, típica de su juventud, su vitalidad y su elegancia. Es de esa manera que quisiera preservarla en mi memoria : un testimonio de belleza e inteligencia que en ella consonaban sin interceptarse, y una comprobación -acaso excepcional- de que la Universidad también puede ser un lugar de encuentro providencial con seres que nos resultarán luminosamente irremplazables. 


\section{RESÚMENES}

Un retrato de Ana María Barrenechea como personalidad destacada de la Facultad y de la vida literaria porteña de los años 60 , mencionando anécdotas, amistades y su desempeño ejemplar.

Un portrait d'Ana María Barrenechea en tant que personnalité remarquable de la Faculté des Lettres et de la vie littéraire de Buenos Aires pendant les années soixante, avec des anecdotes sur ses amitiés, en soulignant la qualité de son parcours professionnel.

A portrait of Ana María Barrenechea, an outstanding scholar at the School of Philosophy at the University of Buenos Aires and also a character of the literary life in Buenos Aires during the sixties, with anecdotes and references to her friends and to her impeccable career.

\section{ÍNDICE}

Mots-clés: Amities, Pizarnik, Onganía, années soixante

Palabras claves: Amistades, Pizarnik, Onganía, los sesenta

Keywords: Friendships, Pizarnik, Onganía, the sixties

\section{AUTOR}

\section{IVONNE BORDELOIS}

Ph.D. MIT (1974).Investigadora independiente en la Universidad de Buenos Aires iabordelois@yahoo.com.ar 